\title{
THE PLASMA MEMBRANES OF EYE LENS FIBRES. BIOCHEMICAL AND STRUCTURAL CHARACTERIZATION*
}

\author{
H.BLOEMENDAL, Anneke ZWEERS, F.VERMORKEN \\ Department of Biochemistry, University of Nijmegen, The Netherlands \\ and \\ I. DUNIA and E.L. BENEDETTI** \\ Department of Electron Microscopy, Institute of Molecular Biology, \\ University of Paris, France
}

Accepted 10 February 1972

\begin{abstract}
Plasma membranes have been isolated from calf eye lens fibre cells. The purified fraction is characterized by the occurrence of a large number of junctional complexes. The cholesterol phospholipid ratio is approximately 0.7 , a value in between the values reported for erythrocyte ghosts and liver plasma membranes. Specific membrane protein components have been separated electrophoretically from structural lens proteins.
\end{abstract}

The eye lens has a number of unique features which makes this organ most suitable for studies of cell differentiation. The main cellular constituents of the lens are the fibres originating from the epithelial cells which exist as a monolayer. During the process of differentiation most of the cellular organelles disappear with exception of the plasma membranes surrounding each individual fibre. The lens, therefore, is one of the best sources for the isolation of plasma membranes since the fibre cells have a high surface-volume ratio (Waley, 1970).

When a lens is dissolved in an aqueous solution by stirring, an insoluble fraction remains containing the so-called albuminoid (Mörner, 1894). Up till now not much attention has been paid to the membranes which are present in the water-insoluble fraction. All attempts to isolate lens membranes have been so far restricted to the fraction which remains insoluble when the albuminoid is extracted by guanidine or urea (Dische et al., 1969). The present paper is dealing with isolation and partial

*Dedicated to Professor H.Veldstra on the occasion of his retirement from the chair of biochemistry of the University of Leiden.

**Part of this work has been carried out while the author was guest professor of the Science Faculty at the University of Nijmegen. 
characterization of the water-insoluble plasma membrane-rich fraction from calf lens cortex.

\section{MATERIALS AND METHODS}

Calf eyes were obtained from the slaughter house and transported on ice to the laboratory. The lenses were isolated and the epithelium and capsula removed. From the remaining tissue only the cortical region, being approximately $50 \%$ of the total lens wet weight was used. Lens tissue ( $120 \mathrm{~g}$ wet weight) was suspended in $200 \mathrm{ml}$ $1 \mathrm{mM} \mathrm{NaHCO}{ }_{3}+1 \mathrm{mM} \mathrm{CaCl}$. The mixture was homogenized in a blender at low speed for $1 \mathrm{~min}$. In a number of experiments the homogenization was carried out in an all-glass Potter-Elvehjem tissue grinder. The homogenate was diluted with $1 \mathrm{mM}$ $\mathrm{NaHCO}_{3}$ to a final volume of 1.5 liter and kept for $5 \mathrm{~min}$ in ice under occasional stirring. Thereafter the homogenate was centrifuged in the GSA rotor of a Sorvall Model RC 2-B centrifuge at $7000 \mathrm{~g}$ for $20 \mathrm{~min}$. The supernatant was decanted and the sediment resuspended in 1.5 liter $1 \mathrm{mM} \mathrm{NaHCO}$. The washing procedure was repeated three times. The final pellet was resuspended in $240 \mathrm{ml}$ bicarbonate and centrifuged in rotor SS 34 of the Sorvall centrifuge at $12,000 \mathrm{~g}$ for $20 \mathrm{~min}$. This crude preparation suspended in $\mathrm{NaHCO}_{3}$ was added to a $81 \%(\mathrm{w} / \mathrm{v})$ sucrose solution. The resulting density in the final volume was $1.22 .13 \mathrm{ml}$ of the latter suspension was transferred to a tube of the SW 27 rotor of the Spinco preparative ultracentrifuge. The following sucrose solutions in volumes of $5.6 \mathrm{ml}$ were layered on top of the sample: $\mathrm{d} 1.20, \mathrm{~d} 1.18, \mathrm{~d} 1.16, \mathrm{~d} 1.14$. Centrifugation was performed at $27,000 \mathrm{rpm}$ for $150 \mathrm{~min}$.

In some experiments the crude preparation resuspended in $40 \mathrm{ml}$ bicarbonate was incubated with a mixture of $50 \mu \mathrm{g}$ trypsin and $50 \mu \mathrm{g}$ chymotrypsin per $\mathrm{ml}$ at $0^{\circ} \mathrm{C}$ for $5 \mathrm{hr}$.

After $5 \mathrm{hr}$ of incubation, $4 \mathrm{mg}$ trypsin inhibitor was added and the suspension was centrifuged at $12,000 \mathrm{~g}$ for $20 \mathrm{~min}$. The pellet was processed as described above. A sucrose layer with a density of 1.08 was added. The volume of each layer was reduced to $4.8 \mathrm{ml}$. Preparations were collected by puncturing the tube walls at the appropriate interface.

\section{Chemical determinations}

Protein was measured according to Lowry et al. (1951) using bovine serum albumin as standard. $P_{i}$ was determined by the method of Fiske et al. (1925). Lipids were extracted as described by Folch et al. (1957) and a factor of 25 was used to convert $\mu \mathrm{g}$ phosphorus to $\mu \mathrm{g}$ phospholipid. Cholesterol was measured according to Zlatkis et al. (1953) at carefully controlled temperature conditions.

The spectrophotometric method for the micro-determination of hexosamine as developed by Dische et al. (1950) was used. Sialic acid content was measured 
according to Warren (1959) applying appropriate correction for deoxyribose contamination. RNA was estimated by the Schmidt-Thannhauser method (1945).

\section{Enzyme assays}

The following enzymic activities were assayed according to the methods given in the references. Total ATPase activity and $\mathrm{Na}-\mathrm{K}$ ATPase activity were determined as described by Bonting et al. (1961). $5^{\prime}$-mononucleotidase was measured as described by Persijn et al. (1970).

Acid phosphomonoesterase was assayed according to Bessey et al. (1946) and alkaline phosphatase was determined with a continuous-flow method using p-nitrophenylphosphate as a substrate (Bessey et al., 1946) and 2-amino-2-methylpropanol-1 as a buffer.

\section{Gel electrophoresis}

Polyacrylamide SDS gel electrophoresis was carried out according to Weber et al. (1969).

Polyacrylamide urea gel electrophoresis was carried out as described by Bloemendal (1963). The 'large-pore' type of gel columns was used which contained $1 \%$ Triton X-100.

\section{Electron microscopy}

Membrane pellets were fixed in the following solutions:

(a) $6 \%$ gluteraldehyde in $0.1 \mathrm{M}$ phosphate buffer, $\mathrm{pH} 7.2$ and postfixed in $2 \% \mathrm{OsO}_{4}$ in the same buffer.

(b) $6 \%$ gluteraldehyde in $0.1 \mathrm{M}$ cacodylate buffer, $\mathrm{pH} 7.2$, and postfixed in $2 \%$ $\mathrm{OsO}_{4}$ in the same buffer. The blocks after repeated washing in Michaelis buffer, $\mathrm{pH} \mathrm{5,} \mathrm{were} \mathrm{stained} \mathrm{in} 2 \%$ uranyl acetate in the same buffer according to Farquhar and Palade (1963).

(c) Lantanum nitrate and potassium permanganate solution according to Lesseps (1967).

All samples after dehydration were embedded in Vestopal W. Thin sections were examined either unstained or double-stained with uranyl acetate and lead citrate. Negative staining was performed on suspensions of membranes in $1.1 \%$ ammonium acetate using potassium phosphotungstate either at $37^{\circ} \mathrm{C}$ or at room temperature.

Freeze-etching of unfixed material was performed in a Balzers apparatus. Some samples were resuspended in $25 \%$ glycerol. The etching time was $1-2 \mathrm{~min}$ at $-100^{\circ} \mathrm{C}$. Electron microscopical observations were made with an EM 300 Philips using $80 \mathrm{kV}$ acceleration voltage. In order to prevent contamination a cooling device was routinely applied. 


\section{RESULTS AND DISCUSSION}

\section{Structural features of the isolated fractions}

The characterization of the lens fibre plasma membrane-rich fraction is based on electron microscopic observations on thin sections of several embedded samples. The crude preparation consists of fibre ghosts still adhering to each other.

Within the ghost some ribosomal clusters and intricate mesh work of filaments adhering to the inner surface of the plasma membranes are visible (fig.1).

Fig.2 illustrates the most common and characteristic structural feature of the fraction found at the interface between densities 1.14-1.16. It can be seen that the material mainly consists of large fragments of membranes having a triple layered structure (fig.2, insert). In this fraction no other recognizable structures such as mitochondria, rough endoplasmic reticulum vesicles or nuclear fragments have been observed. The plasma membranes isolated from two adjacent lens fibres are either running parallel to each other or forming large circular profiles containing vesicular elements of various shape and dimension. These vesicles very likely originate from projections or infolding of the limiting membranes of the lens fibres in specialized regions of the cell surfaces. In addition a large number of junctional complexes are also present. The most common type is characterized by a penta-layered structure resulting from the tight contact of the two adjoining plasma membranes (fig. 2 and insert). The central region of the junction, regardless the type of fixation or embedding technique, seems to lack the clear separation by a uniform 20-30 $\AA$ space as it has been described in the true gap-junction in other tissues (c.f. Benedetti et al., 1971). The intermediate dense lamina is interrupted by a series of narrow intervals, interspaced by tiny regions of fusions of the two outer leaflets. Studies 'still in progress (to be published elsewhere: Dunia et al., 1972) on freeze-etched isolated plasma membranes provide further evidence for the peculiar feature of the junction found in this material. Fig.3 shows an en-face view of freeze-etched isolated lens plasma membranes. At the upper region (PM) the replica reveals that the fracture plane has probably passed throughout the middle of one plasma membrane adjacent to the junctional region. The exposed fracture surface dotted by clusters of particles probably corresponds to the inner aspect of the juxtacytoplasmic leaflet. The fracture then has passed through the junction along its middle region (J). Two cleavage planes are now visible which are not usually seen in other membrane regions. The upper exposed fracture face $\left(J_{1}\right)$ has a rather smooth appearance and is dotted only with a few particles. This layer which may correspond to the interlocking material present in the middle layer, appears to be interrupted in a number of places. Somewhere the fracture has removed from the upper layer very irregularly shaped plaques and exposed the inner face dotted by a number of closely packed particles $\left(\mathrm{J}_{2}\right)$. In other regions small round-shaped plaques have been chipped off from the upper layer $\left(\mathrm{J}_{1}\right)$ and arrays of hexagonally packed subunits are exposed.

Up till now it was generally accepted that the junctions found in lens tissue were 


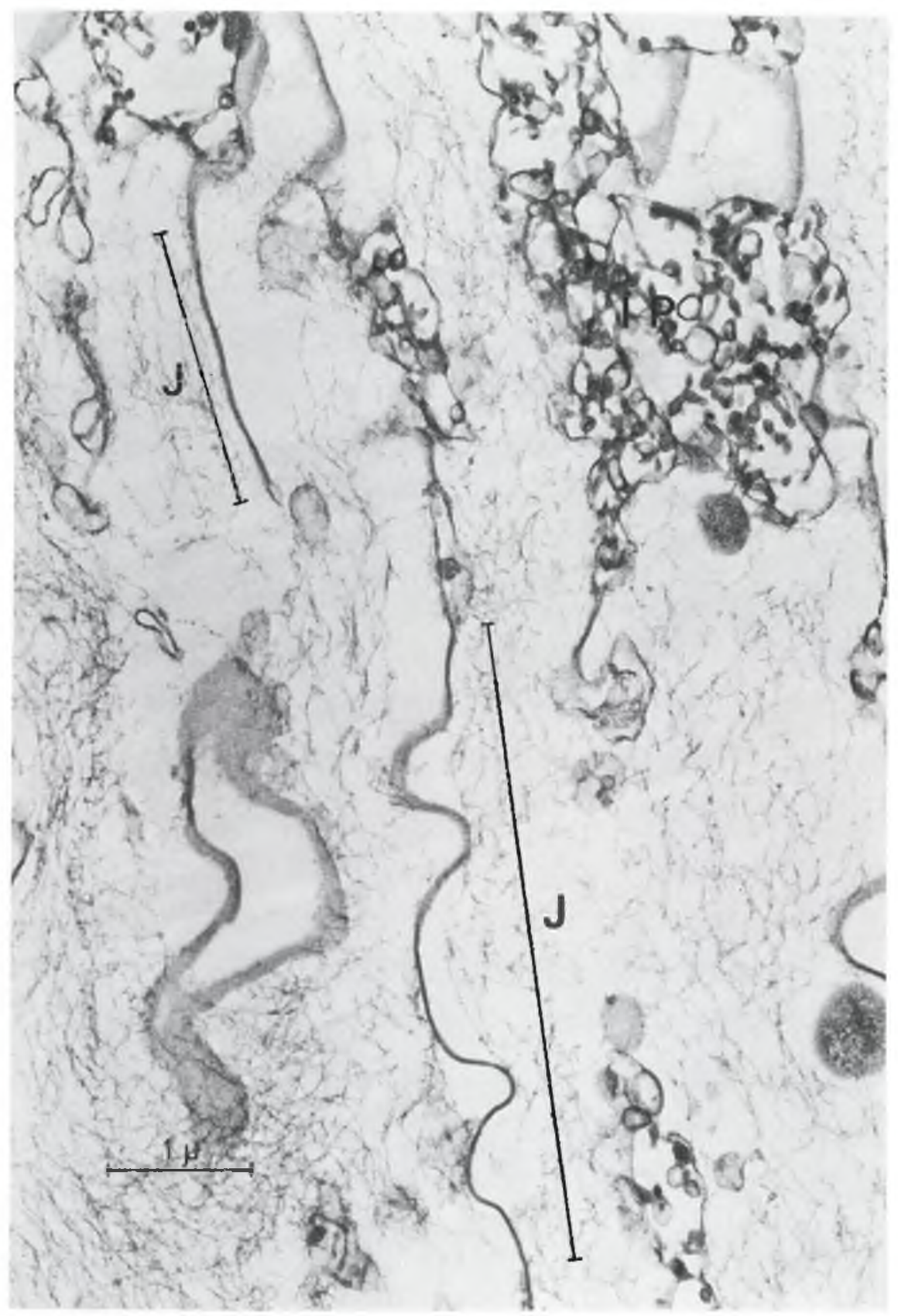

Fig.1. Fibre ghosts still adhering together by junctional complexes (J). Note the presence of large circular profiles containing vesicular elements (IP). 


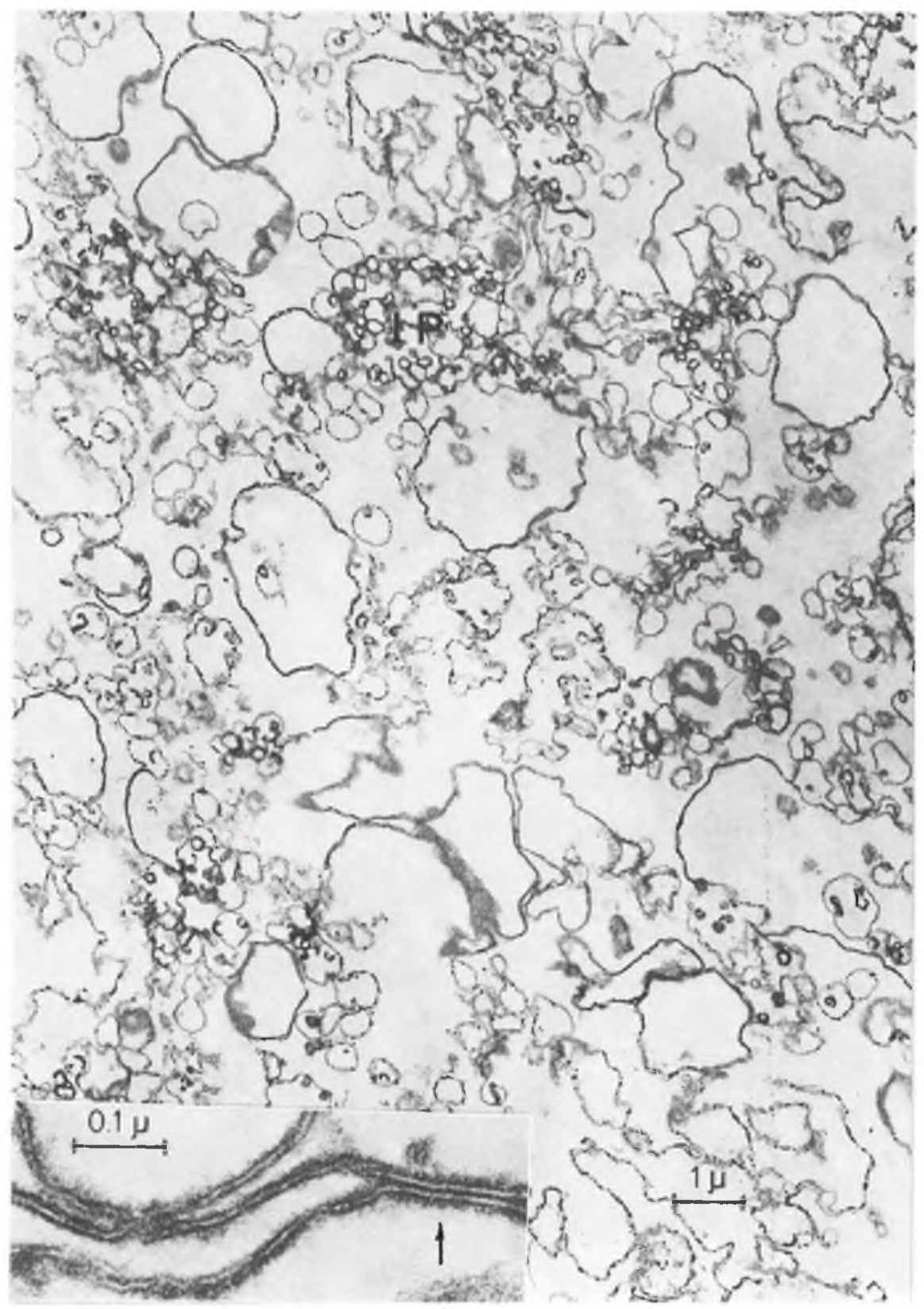

Fig. 2. Isolated lens plasma membranes gathered at the interface between $\mathrm{d} 1.14$ and $\mathrm{d} 1.16$. In the insert the triple-layer structure of the membrane is shown, the arrow points to a junction having a penta-layer feature. A number of vesicular elements (IP) are probably originating from intercellular projections. 


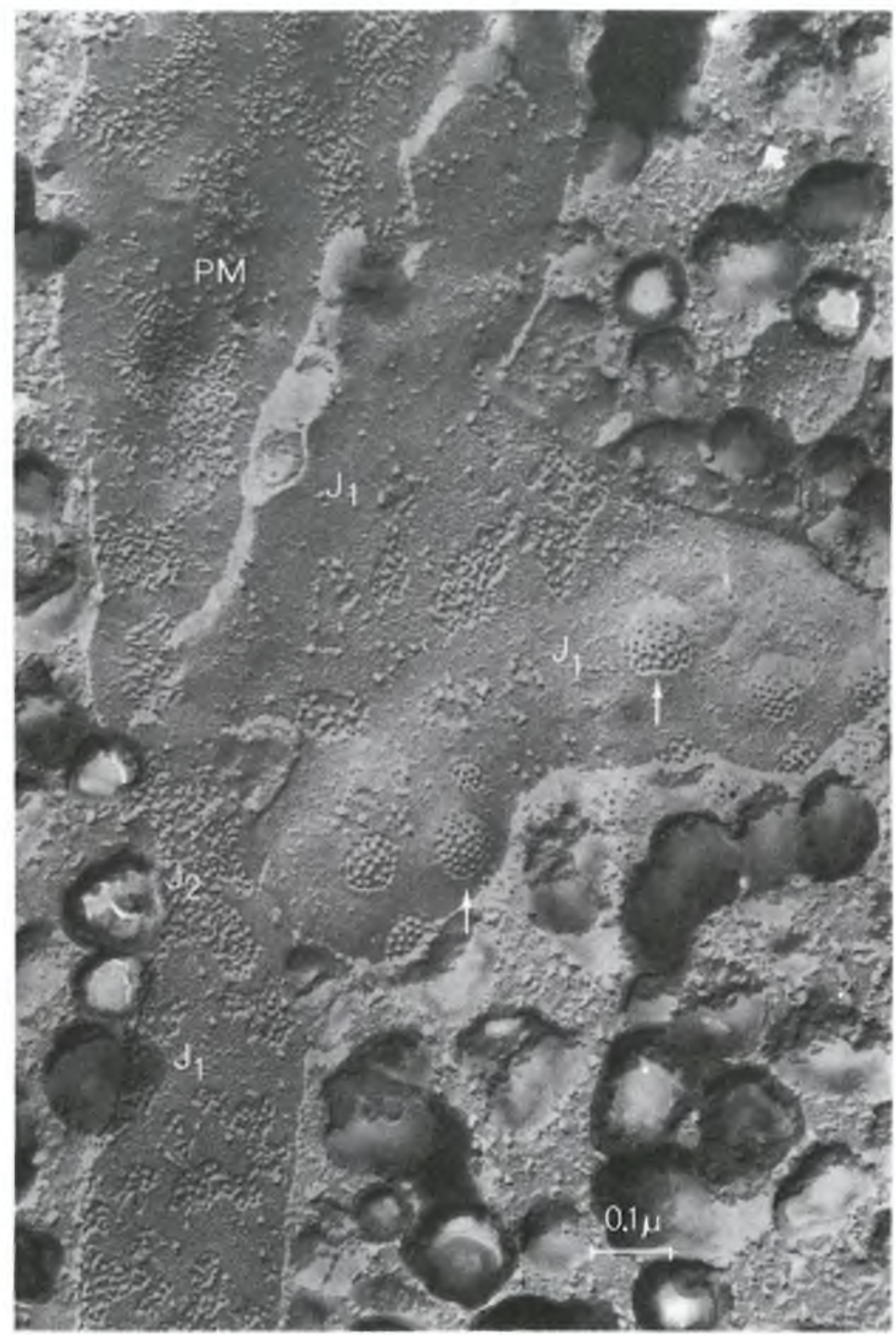

Fig.3. Replica of isolated lens plasma membranes. The upper region (PM) probably corresponds to the inner fracture face of the juxta-cy toplasmic leaflet. $J_{1}$ indicates the fracture face probably corresponding to the middle region of the junction. $J_{2}$ indicates the layer situated underneath which appears to be dotted by a number of particles. The arrows point to the roundshaped areas with a regular lattice of particles. 
true occluded zones or tight junctions (Cohen, 1965; Leeson, 1971; Gorthy et al., 1971). However, our present observations do not allow this conclusion. The tight junctions studied by freeze-etching in other tissue than lens are usually characterized by the presence of interconnected series of concertina-like ridges and of corresponding arrays of interconnected furrows (Chalcroft et al., 1970). This last feature has never been found so far in isolated lens fibre membranes. The structural organization of the lens junction differs also in some respect from the true gap junction present in glandular epithelium such as liver cells. In fact a large fracture surface showing a hexagonal lattice of repeating subunits with $90 \AA$ center-to-center distance characteristic for the gap junction (c.f. Benedetti et al., 1971) has not yet been observed in our material.

It is likely that specific junctions found in different tissues are related to some functional requirement. In lens cortex the remarkable and extensive presence of a peculiar type of junction may be consistent with a suitable design insuring high transport of metabolites and ions from the epithelial monolayer throughout the entire lens and mechanical strength of lens fibres counteracting lens accommodation.

In the fraction found at the interface between densities $1.16-1.18$, membrane fragments showing the same morphological feature as described above are present. Moreover, two other components are observed. One is represented by ribosomal clusters adhering to the membranous sheets via a few monomers (fig.4). The plasma membrane nature of the membranous sheet where polyribosomes are attached could be deduced by the presence of junctional complexes interspaced between the membrane segments. The other component is mostly fibrillar and forms an intricate mesh-work. The filaments have a thickness of about $50 \AA$. They run in different directions and mostly end at the inner surface of the plasma membrane fragments. The attachment of these filaments to the inner surface of the junctional complexes is less obvious.

When the crude preparation of lens membranes is treated with trypsin and chymotrypsin, a membrane fraction is again located at the interface between $d 1.14$ and $d$ 1.16. In contrast with the untreated membrane preparation, the fraction at the interface between $\mathrm{d} 1.16$ and $\mathrm{d} 1.18$ has almost disappeared. Moreover, a rather thick layer at the interface between $\mathrm{d} 1.08$ and $\mathrm{d} 1.14$ is observed. This fraction consists of large membranous fragments having the unit membrane appearance and forming vesicular profiles of various shape and dimension (fig.5). Many junctional complexes are present in this fraction showing the penta-layered structure (compare the insert). The trypsin treatment seems to affect the attachment of the polyribosomes and fibrillar material to the plasma membranes since both components are no longer found in the isolated fractions. In addition, the removal in variable proportions of protein from the membranes (compare table 1) probably affects the buoyant density of the membrane fragments which originate from the plasma membranes and have been found as main constituents in the interface between the d 1.08 and d 1.14 layer. 


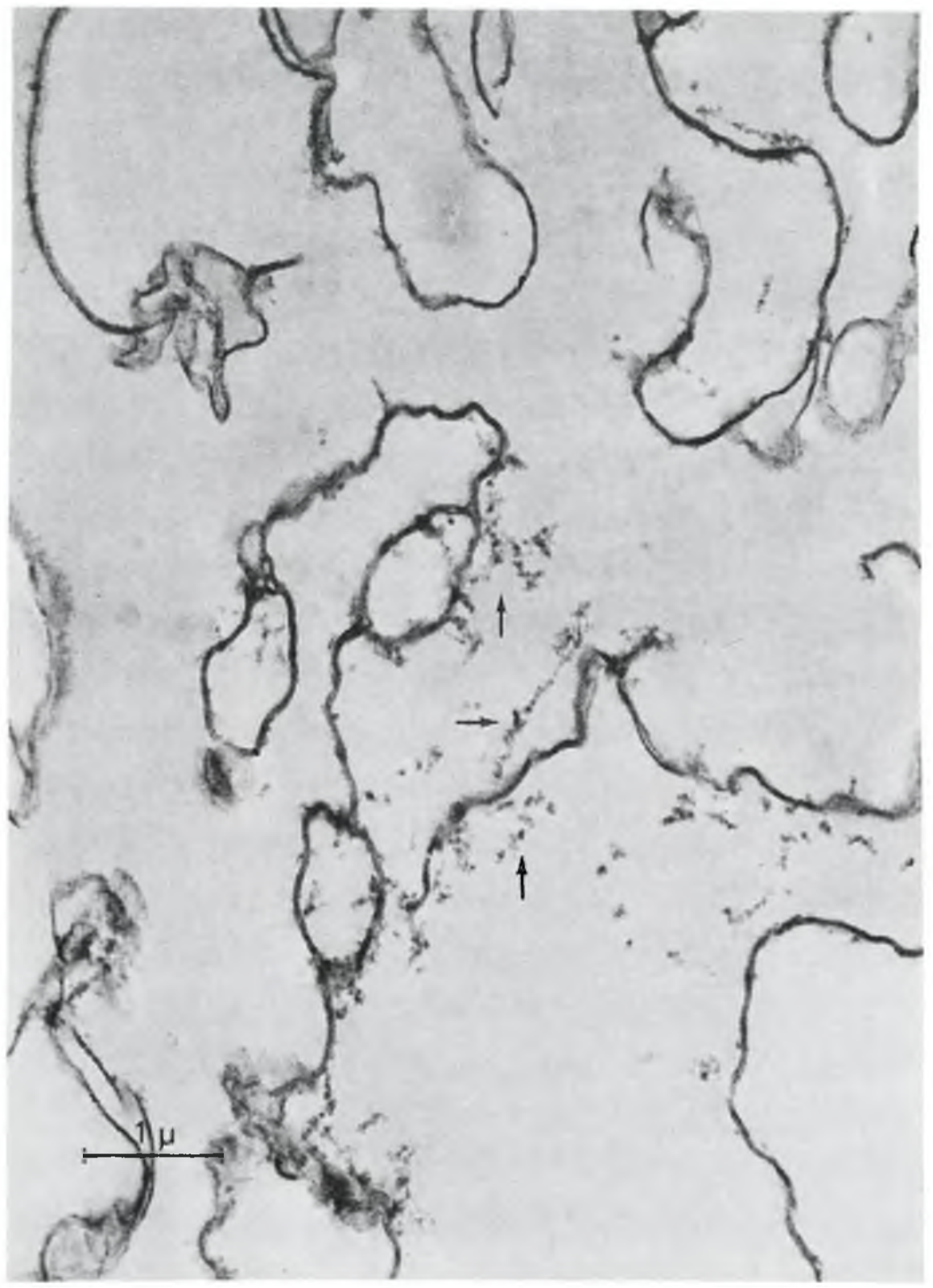

Fig.4. Isolated plasma membranes gathered at the interface between $d 1.16$ and $d 1.18$. The arrows point to the ribosomal clusters attached to the inner surface of the membranes. 


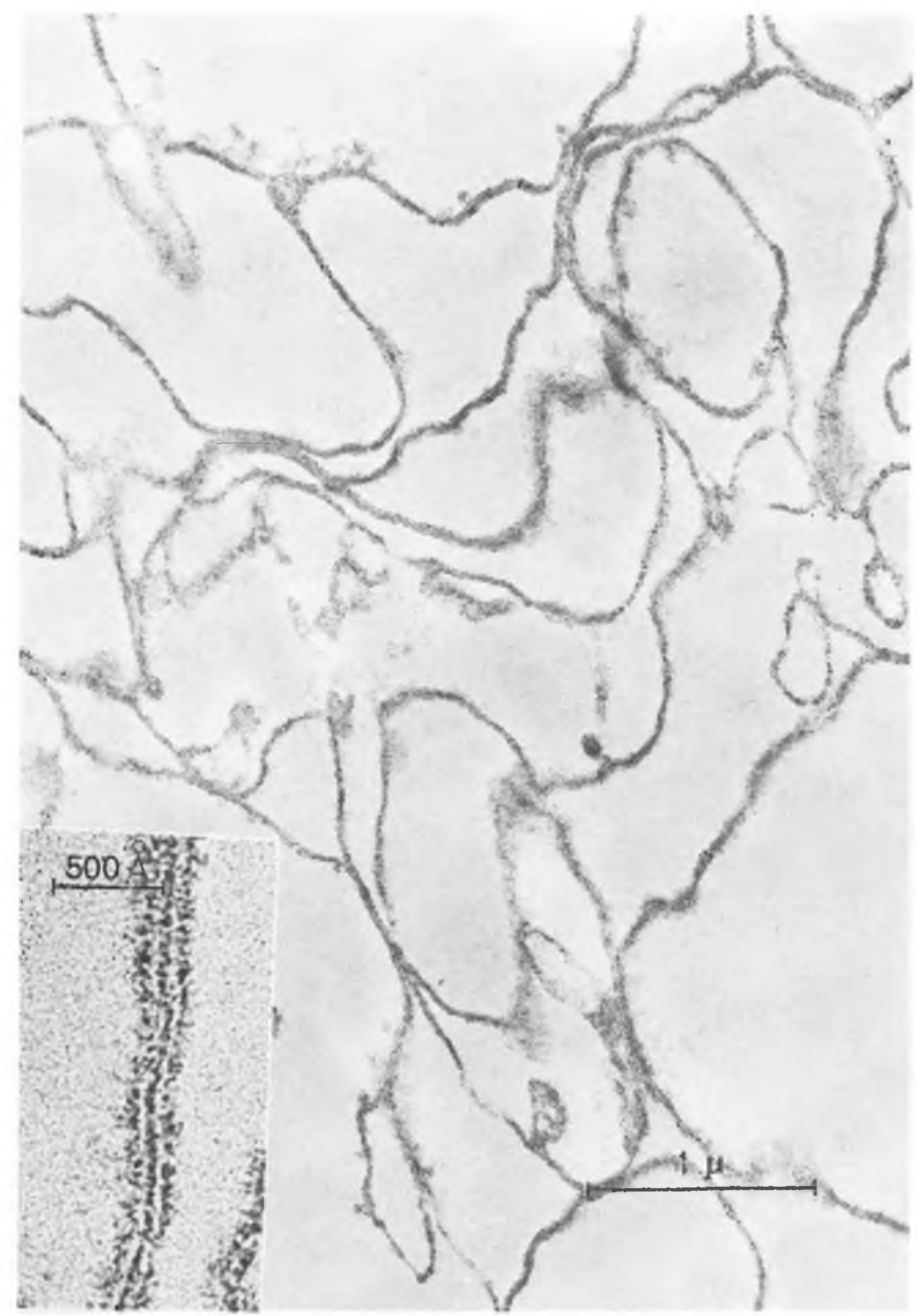

Fig.5. Isolated plasma membranes after treatment with proteolytic enzymes collected at the interface between $d 1.08$ and $d 1.14$. Note the number of junctions present in this fraction. The insert shows the penta-layer structure of the junction. 
Table 1

Gross composition of isolated plasma membranes from calf lens. (The values given are the means of three determinations.)

\begin{tabular}{|c|c|c|c|c|}
\hline \multirow{2}{*}{$\begin{array}{l}\text { Treatment } \\
\begin{array}{l}\text { Interface in the dis- } \\
\text { continuous gradient }\end{array}\end{array}$} & \multicolumn{2}{|l|}{ None } & \multicolumn{2}{|c|}{ Trypsin } \\
\hline & d $1.14-d 1.16$ & d $1.16-d 1.18$ & d $1.08-\mathrm{d} 1.14$ & d $1.14-d 1.16$ \\
\hline $\begin{array}{l}\text { Yield (mg protein } / 100 \\
\text { g wet wt. of lens } \\
\text { cortex }\end{array}$ & 32 & 14.6 & 47.5 & 42 \\
\hline Total lipid (mg/mg & & & & \\
\hline $\begin{array}{l}\text { protein) } \\
\text { Phospholipid (mg/mg }\end{array}$ & 1.25 & 1.00 & - & - \\
\hline $\begin{array}{l}\text { protein) } \\
\text { Percentage phospho- }\end{array}$ & 0.58 & 0.39 & 0.77 & 0.72 \\
\hline lipid of total lipid & 46 & - & - & - \\
\hline $\begin{array}{l}\text { Cholesterol (mg/mg } \\
\text { protein) }\end{array}$ & 0.202 & 0.168 & 0.268 & 0.240 \\
\hline $\begin{array}{l}\text { Molar ratio cholest- } \\
\text { erolyphospholipid }\end{array}$ & 0.69 & 0.86 & 0.70 & 0.67 \\
\hline $\begin{array}{l}\text { Sialic acid } \mathrm{H}_{2} \mathrm{SO}_{4} \text { hydrol- } \\
\text { ysis (nmol/mg protein) }\end{array}$ & 25.6 & 21.4 & 25.9 & - \\
\hline $\begin{array}{l}\text { Neuraminidase hydrolysis } \\
\text { (nmol/mg protein) }\end{array}$ & 19.1 & 17.6 & 243 & - \\
\hline Hex osamine $\mathrm{HCl}$ hy drol- & & & & \\
\hline ysis (nmol/mg protein) & 128 & 95 & 140 & 157 \\
\hline RNA ( $\mu \mathrm{g} / \mathrm{mg}$ protein) & 0.8 & 1.8 & 0.6 & - \\
\hline
\end{tabular}

\section{Electrophoretic characterization}

The common procedure to determine the number and variety of membraneprotein components is polyacrylamide gel electrophoresis. Membrane proteins are, as a rule, separated more easily in a detergent than in a non-detergent gel system. In urea-containing gels at alkaline $\mathrm{pH}$ the water-soluble lens proteins dissociate into a number of polypeptide chains (Bloemendal et al., 1962). If this method is applied to solubilized plasma membranes two bands are localized in the same position as the acidic polypeptide chains of $\alpha$-crystallin. Staining for lipoprotein and glycoprotein reveals that a third component on this type of gels is membrane specific (fig.6). Since these stainings occur in exactly the same position it is hard to draw definite conclusions concerning the nature of this component. Either of the three following possibilities may be envisaged.

(1) The band represents a lipo-glycoprotein.

(2) Either a lipid or a sugar residue is linked to the same protein.

(3) A lipid or a sugar residue is linked to different proteins resulting in two components with the same electrophoretic mobility.

Polyacrylamide electrophoresis on SDS gels allows a clearcut separation of 


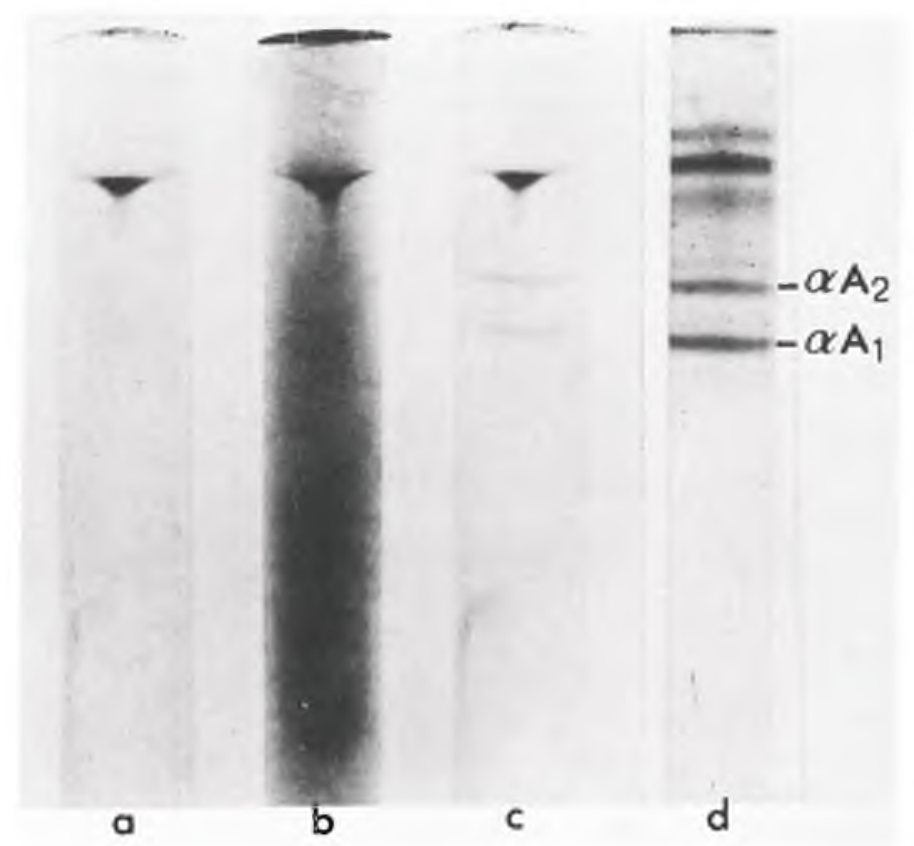

Fig.6. Gel electrophoresis of solubilized lens plasma membrane proteins on polyacrylamide gels containing $7 \mathrm{M}$ urea at $\mathrm{pH} \mathrm{8.9;} \mathrm{(a)} \mathrm{staining} \mathrm{with} \mathrm{oil} \mathrm{red} \mathrm{O}$; (b) staining with periodic Schiff reaction; (c) staining with amido black; (d) for comparison the pattern of water-soluble lens proteins under the same conditions is given.

water-soluble lens proteins from membrane protein (fig.7). Despite extensive washing of the membrane preparation, as described in the Methods section, watersoluble lens protein components are detected in all electropherograms (compare fig. $7 \mathrm{a}$ with $7 \mathrm{~b}-\mathrm{e}$ ). Especially $\alpha$-crystallin seems to be tightly bound to membranes. In this connection it has to be mentioned that Bracchi et al. (1971) demonstrated a selective binding of aged $\alpha$-crystallin to lens fibre ghosts. One may question whether this interaction between the crystallins and the plasma membrane is an essential feature of the lens whose main function is its role in vision. The possibility exists that controlled interaction between crystallins and membrane components is a structural requirement for the maintenance of correct refraction.

Trypsin treatment of the lens membranes has a striking effect on the electrophoretic band pattern (compare fig.7e). The high molecular weight components virtually disappear while the mobility of the predominant band (PB) slightly increases. On the other hand the so-called B chains of $\alpha$-crystallin (Bloemendal, 1969) seem to be unaffected by trypsin. The strong interaction between watersoluble lens crystallins and the membranes is further demonstrated by the observation that $7 \mathrm{M}$ urea treatment of the solubilized membranes does not result in 


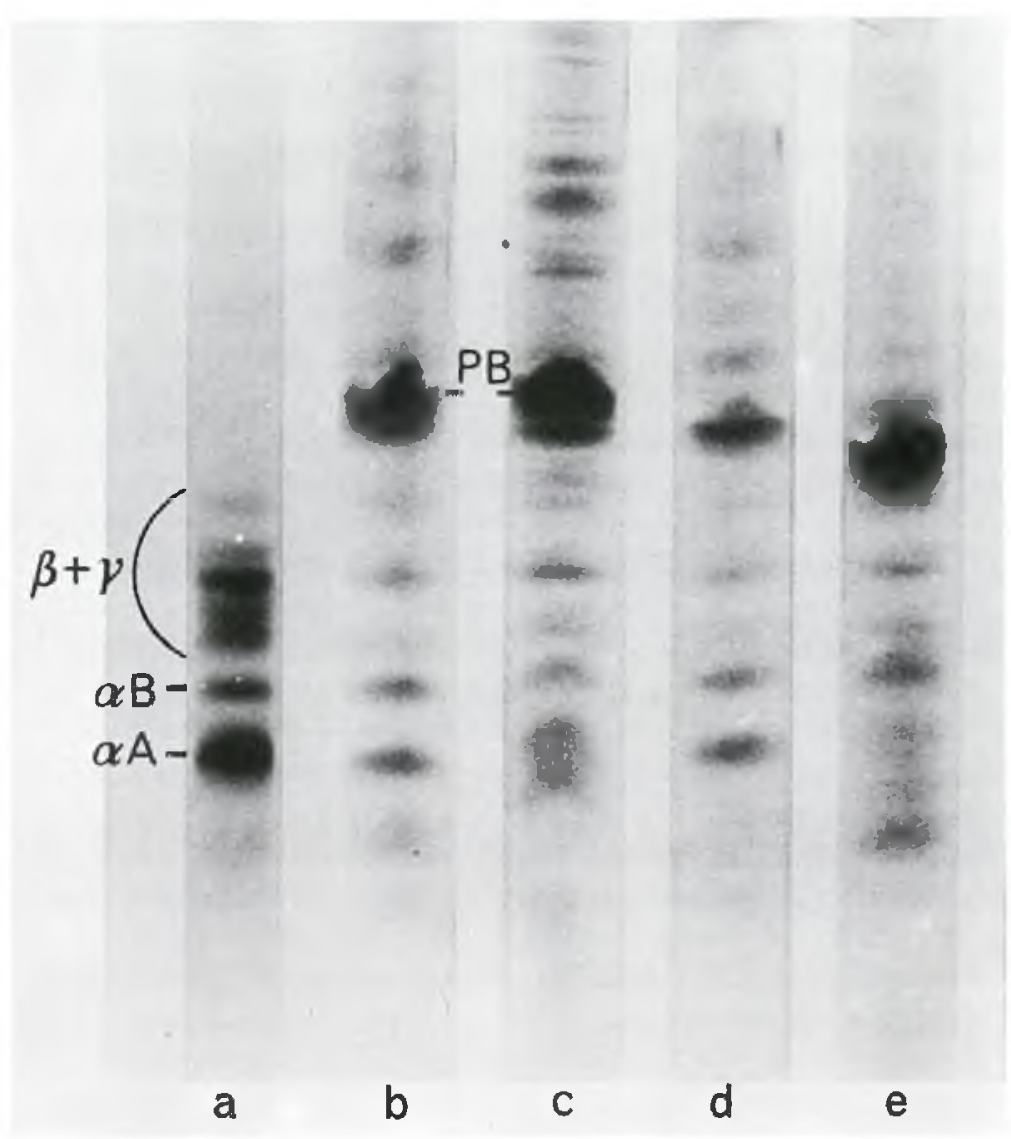

Fig.7. Gel electrophoresis of solubilized lens plasma membrane proteins on polyacrylamide gels containing SDS; (a) for comparison the pattern of water-soluble lens proteins is shown; (b) purified lens plasma membrane fraction solubilized in $1 \%$ SDS $+1 \%$ mercaptoethanol; (c) membrane fraction (b) insoluble in $7 \mathrm{M}$ urea; (d) membrane fraction (b) soluble in $7 \mathrm{M}$ urea; (e) membrane fraction derived from trypsin-treated crude preparation. Electrophoresis was performed on $14 \mathrm{~cm}$ poly acrylamide gel columns containing $0.1 \%$ SDS, $5 \mathrm{~mA}$ per gel tube for $13-14 \mathrm{hr}$.

complete removal of the crystallins (fig.7c). In conclusion purified lens membranes apparently contain one predominant component (PB) which always has a fuzzy appearance. The molecular weight of this component has been estimated at approximately 38,000 dalton by the method of Shapiro et al. (1967).

\section{Biochemical characterization}

A number of chemical characteristics of isolated lens plasma membrane fractions are summarized in table 1 . From the values listed it appears that the molar ratio of 
cholesterol to phospholipid is higher than in liver plasma membranes (Emmelot et al., 1964; Ashworth et al., 1966) and lower than in erythrocyte ghosts and myelin (Ashworth et al., 1966).

The total lipid content is comparable to that reported for highly purified rat liver plasma membranes (Coleman et al., 1967).

Neuraminidase liberates $73 \%$ of the total sialic acid content as in rat liver plasma membranes (Benedetti et al., 1968). After mild proteolytic treatment neuraminidase action releases almost $93 \%$ of terminal sialic acid. Presumably sialic acid is better exposed after this treatment. This observation seems to be consistent with the fact that after trypsin digestion the sugar non-terminal residues of the cell surface are more easily accessible to phytagglutinin-binding (Nicholson, 1971). The RNA content is very low in the membrane fraction which concentrates at the interface between $d 1.14$ and $d$ 1.16. As expected in the $d 1.16-d 1.18$ layer where ribosomal clusters were observed, the RNA content is somewhat higher. Preliminary enzymatic estimation of $\mathrm{Na}^{+}-\mathrm{K}^{+}$ATPase revealed that in the isolated membranes from the lens cortex only residual activities are present. This is in agreement with earlier observations of Bonting et al. (1961), who found that this enzyme exists with high specific activity only in the epithelium where active transport is located. Acid phosphatase occurs with specific activity of 8.4 units $/ \mathrm{mg}$ protein in the lens cortex plasma membrane.

Whether this activity is due to lysosomal contamination cannot be completely ruled out. However, the lysosomal structure has not so far been demonstrated in the isolated lens plasma membrane preparation. Acid phosphatase has been reported to be more concentrated in the epithelium than in other lens regions (Gorthy et al., 1971). Acid phosphomonoesterase activity has been found in liver plasma membranes (Emmelot et al., 1964) where lysosomal contamination could be excluded by other enzyme markers. Therefore, it is not unlikely that acid phosphomonoesterase can also be considered to be an intrinsic lens plasma membrane enzyme.

$5^{\prime}$-Nucleotidase could only be detected as trace amounts. The value is even lower than that found in hen erythrocyte plasma membranes (Zentgraf et al., 1971).

\section{CONCLUSIONS}

The vertebrate eye lens fibre provides a unique cell system which comprises essentially one kind of membrane namely the plasma membrane. Plasma membrane fractions have been isolated from the cortical region of calf lenses using discontinuous density gradient centrifugation. Electron microscopy studies revealed a high degree of homogeneity of the plasma membrane fraction which accumulated at the interface between densities 1.14 and 1.16. Membranes bearing ribosomal clusters gathered at the interface between densities of 1.16 and 1.18. After trypsin treatment of the crude membrane preparation a purified fraction concentrated at the interface between densities of 1.08 and 1.14. The isolated membranes are characterized by the presence of a peculiar type of junction which can be distinguished 
both from the true tight junction and from the gap junction found in various epithelial tissues.

Electrophoresis on SDS-containing polyacrylamide gels allows distinction between structural lens proteins (crystallins) and membrane proteins. The latter have a higher molecular size than the polypeptide chains of the crystallins. The number of specific membrane-protein components is limited. This result is in agreement with the concept reported for other types of membranes by Hinman et al. (1970). On the other hand, strong interaction between the crystallins and lens plasma membranes is observed. For the time being the question whether this interaction is functional cannot be answered.

Preliminary findings of Broekhuyse (1971) revealed that during lens differentiation a drastic change in lipid composition occurs. It may be expected that the method described in the present paper will enable a better characterization of the changes of membrane structure and composition during cell differentiation, a process which takes place in the lens throughout its whole life span.

\section{REFERENCES}

Ashworth, L.A.E. and C.Green: Science 151, 210-212 (1966).

Benedetti, E.L. and P.Emmelot: in: The Membranes, eds. A.J.Dalton and F.Hagueman (Academic Press, New York) pp.33-120 (1968).

Benedetti, E.L. and D.Delbauffe: in: Cell Membranes: Biological and Pathological Aspects (The American Association of Pathologists and Bacteriologists) pp.54-84 (1971).

Bessey, O.A., O.H.Lowry and M.J.Brock: J. Biol. Chem. 164, 321-329 (1946).

Bloemendal, H.: Zone Electrophoresis in Blocks and Columns (Elsevier, Amsterdam) pp.64-66 (1963).

Bloemendal, H.: Exptl. Eye Res. 8, 227-240 (1969).

Bloemendal, H., W.S.Bont, J.F.Jongkind and J.H.Wisse: Exptl. Eye Res. 1, 300-305 (1962).

Bonting, S.L., K.A.Simon and N.M.Hawkins: Arch. Biochem. Biophys. 95, 416-424 (1961).

Bracchi, P.G., F.Carta, P.Fasella and G.Maraini: Exptl. Eye Res. 12, 151-154 (1971).

Broekhuyse, R.M.: Lens Symposion, Abstract (University of Utrecht) (1971).

Chalcroft, J.R. and S.Bullivant: J. Cell Biol. 47, 49-60 (1970).

Cohen, A.I.: Invest. Oph thalmol. 4,433-446 (1965).

Coleman, R., R.H.Michell, J.B.Finean . and J.N.Hawthorne: Biochim. Biophys. Acta 135, 573-579 (1967).

Dische, Z. and E.Borenfreund: J. Biol. Chem. 184, 517-522 (1950).

Dische, Z., M.A.Hairstone and G.Zelmenis: Protides Biol. Fluids, Proc. Colloq. 15, 123-129 (1969).

Dunia, I., E.L.Benedetti and M.M.A.Sassen: manuscript in preparation (197.2).

Emmelot, P., C.J.Bos, E.L.Benedetti and Ph.Ruimke: Biochim. Biophys. Acta 90, 126-145 (1964).

Farquhar, M.G. and G.E.Palade: J. Cell Biol. 17, 375-412 (1963).

Fiske, C.H. and Y.Subbarow: J. Biol. Chem. 66, 375-400 (1925).

Folch, J., M.Lees and G.H.Sloane Stanley: J. Biol. Chem. 226, 497-510 (1957).

Gorthy, W.C., M.R.Snavely and N.D.Berrong: Exptl. Eye Res. 12, 112-119 (1971).

Hinman, N.D. and A.H.Phillips: Science 170, 1222-1223 (1970). 
Leeson, T.S.: Exptl. Eye Res. 11, 78-82 (1971).

Lesseps, R.J.: J. Cell Biol. 34, 173-183 (1967).

Lowry, O.H., N.J.Rosebrough, A.L.Farr and R.J.Randall: J. Biol. Chem. 193, 265-276 (1951). Mörner, C.Th.: Hoppe-Seylers Z. Physiol. Chem. 18, 61-106 (1894).

Nicolson, G.L.: Nature 233, 244-246 (1971).

Persijn, J.P. and W.van der Slik: Klin. Chem. 8, 398-402 (1970).

Schmidt, G. and S.J.Thannhauser: J.Biol. Chem. 161, 83-89 (1945).

Shapiro, A.L., A.L.Vinuela and J.V.Maizel: Biochem. Biophys. Res. Commun. 28, 815-821 (1967).

Waley, S.G.: in: The Eye, ed. H.Davson (Academic Press, New York) pp.291-379 (1970).

Warren, L.: J. Biol. Chem. 234, 1971-1975 (1959).

Weber, K. and M.Osborn: J. Biol. Chem. 244, 4406-1413.

Zentgraf, H., B.Deumling, E.D.Jarasch and W.W.Franke: J. Biol. Chem. 246, 2986-2995 (1971).

Zlatkis, A., B.Zak and A.J.Boyle: J. Lab. Clin. Med. 41, 486-492 (1953). 